\title{
An Episodic Process Model of After-Hour ICT-Related Interruptions at Home
}

\author{
Angela R. Grotto \\ Manhattan College, USA \\ Correspondence should be addressed to Angela R. Grotto; angela.grotto@manhattan.edu
}

Received 8 October 2021; Revised 18 January 2022; Accepted 19 January 2022; Published 17 February 2022

Academic Editor: Zheng Yan

Copyright (c) 2022 Angela R. Grotto. This is an open access article distributed under the Creative Commons Attribution License, which permits unrestricted use, distribution, and reproduction in any medium, provided the original work is properly cited.

\begin{abstract}
As remote and hybrid work become mainstream, after-hour interruptions from work into personal life (i.e., boundary violations) via information communicative technology will become even more prevalent. These interruptions trigger employees to suddenly disengage from their nonwork roles and reengage in work (i.e., interrole transitions), which can translate into adverse work and well-being outcomes for employees. It is critical to study after-hour ICT-related interruptions to ensure employees can effectively perform in both their work and nonwork spheres. Although there is a substantial knowledge base for boundary violations and interrole transitions, we have limited understanding of the mechanisms through which these experiences affect individuals on a daily basis. The present study builds on boundary theory with a comprehensive qualitative investigation of the boundary violation-interrole transition process and development of an episodic process model grounded in data. Using the event reconstruction method, employee experiences with after-hour ICT-related interruptions were deeply explored. Content analysis revealed defining features and underlying mechanisms of the boundary violation-interrole transition process and the interrelationships of these mechanisms, facilitating the development of an episodic model with testable propositions for future boundary research. The results suggest that after-hour ICT-related interruptions are a particular type of perceived work-family incompatibility that can be problematic for employees, thereby advancing work-family theory. As these interruptions cannot be eliminated and will increase as more employees work remotely, the results and proposed model can inform the design of organizational interventions intended to mitigate the negative effects of interruptions on employees' daily lives.
\end{abstract}

\section{Introduction}

Work-related information and communicative technologies (ICTs; e.g., mobile phones, email communication, group chats, conferencing technology, social media technologies, etc.) are increasingly blurring the interface where work and family meet [1]. Unexpected interruptions from work at home represent an ICT demand that pressures employees to flex their work boundaries and allow work to infiltrate into their home lives, resulting in the use of ICTs during nonwork time [2-5]. A misalignment between the purpose of ICT use (i.e., for work) and context of use (i.e., at home) can make interruptions at home feel like violations of personal boundaries, as personal goals and tasks are disrupted by work $[2,3,6,7]$. For example, when a disgruntled client unexpectedly calls an employee on Saturday, and the employee returns the call, it may disrupt time with family.
Work-related ICT use during nonwork time can be a double-edged sword. Despite having the potential to boost productivity (e.g., completion of unfinished work tasks), the task switching and multitasking behavior it requires can be emotionally and physically taxing, as one must suddenly shift mindsets and behaviors and redirect scarce personal resources (e.g., energy; [2, 8-10]). Indeed, constant connectivity and interrole transitions have been associated with negative affect, work-family conflict, and impaired well-being [11-17].

Despite substantial knowledge on the consequences of ICT-related interruptions and ICT use during nonwork time (for a review, see [18]), Hu et al. [3] recently called for "more empirical work to develop systematic approaches to address the proliferation of technology-related constructs and theoretical developments, which helps build testable models that comprehensively capture emerging ICT constructs" (p. 218). 
Moreover, Ashforth et al.'s [2] call for more research specifying the mechanisms that underly how individuals manage their work and nonwork boundaries remains largely unanswered 20 years later. Consequently, scholars and practitioners have limited understanding of the mechanisms through which interruptions at home and their associated responses negatively affect individuals. The present study was designed to comprehensively examine the interruption-response experience and develop a process model illuminating how and why interruptions at home translate into interrole transitions and then affect employees in different ways. In line with $\mathrm{Hu}$ et al.'s recommendation, this study can contribute to the work-family (WF) and ICT bodies of literature by building a testable data-driven model that comprehensively captures the lifespan of an interruption at home. Moreover, a process model for interruptions at home complements Puranik et al.'s [19] process model of interruptions at work, which delineates how, when, and why interruptions at work affect employees in different ways.

Based on event systems theory, events occur in a particular time and space and include features (e.g., duration) and processes (e.g., how events lead to outcomes; [20]). Similarly, ICT-related interruptions from work occur at home during nonwork hours, encompassing features (e.g., message content and tone) and processes (e.g., stimulated responses). The catalyzation of a response would be difficult to understand at a levels perspective which addresses general experiences with ICT-related interruptions. An event-driven approach to studying ICT-related interruptions and the interrole transition responses they require can facilitate the development of a process model. Thus, the present study takes an episodic approach by examining discrete ICTrelated interruptions at home and subsequent responses, including an investigation of the underlying cognitive, affective, and behavioral processes of these events [21]. Episodes were deeply explored in a qualitative manner to capture rich and detailed information covering the full range of underlying mechanisms as well as the defining characteristics of interruptions and responses $[22,23]$. In the next section, theoretical background on interruptions at home and interrole transitions is provided, forming the basis for the study's research questions.

\section{Review of the Literature}

2.1. ICT-Related Interruptions. Boundary theory is the foundation for ICT-related interruptions; it is a general cognitive theory of social classification $[24,25]$ that focuses on what different social domains (e.g., home and work) mean to individuals [26]. Boundaries demarcate the point at which domain-relevant behavior begins or ends [2,27]. Boundaries can be spatial (i.e., define where domain-relevant behavior takes place), temporal (i.e., define when a role should be performed), or psychological (i.e., rules that dictate when thinking patterns and emotions are appropriate for one domain but not the other). Firm (i.e., inflexible and impermeable) boundaries help keep work and nonwork separated by space, time, and thoughts, with individuals differing in the type of content (e.g., behaviors) they think belongs and does not belong to each domain [26]. However, constant advancements in work-related ICTs allow workers to increasingly flex their work boundaries such that the work role can be enacted in nonwork settings during nonwork hours and has made nonwork boundaries more permeable such that one can be physically located at home while involved in the work role $[2,26,28]$.

While the use of work-related ICTs at home during nonwork hours can be advantageous for employees and employers (e.g., productivity boosts; [18]), it also enables work to unexpectedly interrupt personal time. When a domain-irrelevant behavior (i.e., work) must be enacted at home during nonwork hours, it can feel like a violation of personal boundaries, as there is a clear misalignment between the purpose of ICT use (i.e., for work) and context of use (i.e., at home). Boundary violations at home are workrelated behaviors, events, or episodes that breach a desired nonwork boundary [8]; they can have many negative consequences including making employees feel tethered to their jobs, [29], interrupting nonwork tasks [7], obstructing the achievement of personal goals [6], impairing work performance [13], and-most relevant to the present study-necessitating involuntarily shifts back to the work role (i.e., unplanned interrole transitions; [2]) when one should be recovering from workday demands. Moreover, these interruptions may negatively impact other individuals who are present at the time of the interruptions. For example, ICTrelated interruptions at home were found to trigger affective strain in both employees and their partners [30] and create interference with workers' family lives [31].

Much of the prior research on ICT-related interruptions at home has focused on general tendencies for after-hours ICT use $[9,32-34]$ or the impact of ICT use during nonwork time on individuals $[7,11-14,16,29,33,35-40]$. There is a need to go beyond investigating the occurrence of ICTrelated interruptions during nonwork hours to deeply examining individuals' experiences with discrete interruptions, which would allow for the examination of features and perceptions of interruptions. Although features of interruptions at work from family have been well delineated [41], little attention has been paid to the defining characteristics of interruptions at home from work, with very few exceptions (e.g., sender tone, e.g., [42]). In regards to perceptions, Horvath et al.'s [43] research on interruptions at work from family found that perceived importance and severity were key factors predicting individuals' reactions. Yet, there has been no commensurate research conducted for interruptions at home from work, with one exception wherein Hunter et al. [6] investigated the extent to which interruptions from work were perceived as obstructing versus facilitating family goals. A better understanding of the important characteristics of ICT-related interruptions (e.g., timing, content, tone) and how these events are perceived (e.g., legitimacy) may help clarify the link with interrole transitions.

Research question 1: What are the central characteristics of ICT-related interruptions at home?

2.2. Interrole Transitioning. ICT-related interruptions at home necessitate hurried prioritization of work over 
family [44] and unplanned transitions back to the work role [2]. Ashforth et al. [2] defined role transitioning as a boundary-crossing activity that involves the exiting and entering of roles by surmounting boundaries, including transitions between roles from different life domains (e.g., work and family). According to Clark's [27] work-family border theory, flexible and permeable (i.e., weak) boundaries allow for transitions between different life roles (e.g., worker and parent) while physically located in one domain (e.g., home). As such, weak work-nonwork boundaries not only enable work to interrupt nonwork life, as described previously, but also allow for transitions from nonwork roles to the work role while at home. Clark [45] argued that individuals may lack control over when work invades the home, but did not address what this means for the interrole transitions that follow. Matthews and Barnes-Farrell [9] introduced two critical dimensions of interrole transitions-the ability to transition between roles (e.g., with the use of ICTs) and the willingness to do (e.g., based on preferences to integrate versus segment different life roles). Thus, an important feature of interrole transitions that has not received attention is their planned versus unplanned nature. This distinction seems essential given that ICT-related interruptions likely vary in their predictability. Also, as hybrid and remote work become more commonplace, ICT-related interruptions from work are ubiquitous, which all but guarantees unplanned interrole transitions for employees.

It is important to understand the defining qualities of unplanned interrole transitions, as prior theory and research suggest that these experiences maybe be even more detrimental to individuals than planned interrole transitions. Interrole transitions in general can be mentally and physically difficult, as the shifts in mindsets and behaviors needed to disengage from one role and reengage in another role require mental and physical effort [2]. Additionally, switching mindsets and multitasking consume self-regulatory and personal resources $[10,46]$, which can impair performance [47]. Further, interrole transitions at home may to contribute to negative affect, work-to-family conflict, and impaired well-being [11-17, 29, 33, 35]. Building on these premises, unplanned interrole transitions may be especially problematic for individuals since they require very sudden and unexpected shifting of behaviors and mindsets and unanticipated consumption of resources during a time of the day when individuals should be recovering from workday demands. Thus, in addition to suffering the abovementioned consequences of ICT-related interruptions, subsequent unplanned interrole transitions may further strain individuals. Identifying the most important qualities of unplanned interrole transitions can help clarify why these experiences are problematic.

Research question 2: What are the defining qualities of unplanned interrole transitions in response to ICT-related interruptions at home?

\subsection{The ICT-Related Interruption and Interrole Transition} Process. As aforementioned, although boundary theory and research suggest that ICT-related interruptions are likely to trigger interrole transitions, the underlying mechanisms connecting these two experiences remain unclear, as there is no comprehensive model depicting this important WF process. Maertz et al.'s [48] model of WF conflict processing is focused on events that trigger perceptions of WF role incompatibility and the resulting affective, cognitive, and behavioral responses. Yet, the authors acknowledged that their theory is somewhat general and omits many specific intraepisode predictions for future theoretical and empirical work. In particular, they reason that the processing of WF conflict episodes may depend on the specific type of WF incompatibility experienced. ICT-related interruptions at home are a very particular type of WF conflict episode, warranting a process model to advance boundary theory. A comprehensive model focused on this particular part of $\mathrm{Hu}$ et al.'s [3] taxonomy for ICT constructs may also help build a testable model that systematically portrays an evolving ICT construct-ICT-related interruptions from work at home.

Since we likely cannot ban work-related ICTs and thus cannot eliminate ICT-related interruptions at home [49], the present study sought to identify the underlying processes that translate ICT-related interruptions at home into interrole transition responses and subsequently adverse outcomes for individuals. Deeply exploring discrete episodes of ICTrelated interruptions at home may help improve our understanding of how and why individuals react and respond to interruptions as well as the consequences. These relationships are critical to understand with the increasing prevalence of ICTs and remote work further blurring the workfamily interface [50-52]. Specifically, the following questions helped build an episodic process model.

Research question 3: What are the underlying mechanisms and outcomes of unplanned interrole transitions?

Research question 4: How are ICT-related interruptions at home and the associated interrole transitions linked with each other?

\section{The Present Study}

Two phases of qualitative exploration were conducted on discrete episodes of work interrupting at home via ICTs, subsequent interrole transitioning responses, and outcomes. A qualitative approach allowed for the collection of rich and detailed information that fully captures this interruptionresponse process. Phase one focused on the stimulus (i.e., interruption) and response (i.e., interrole transition) process, with the goals of identifying (1) key characteristics of unexpected ICT-related interruptions at home that distinguish them from expected work during nonwork time (e.g., invited phone calls from clients) and (2) defining features of the unplanned interrole transitions that these interruptions beget. Phase two was designed to (1) identify the underlying mechanisms of the interruption-response at an episodic level and (2) clarify the mechanisms linking interruptions, interrole transitions, and outcomes. Results from both phases were expected to help facilitate the development of an episodic process model grounded in data with testable propositions, which can inform future quantitative research and then be translated into organizational intervention plans and strategies. 


\section{Method and Results}

4.1. Phase 1 Sample and Procedure. Phase one was designed to identify the key characteristics of ICT-related interruptions at home and the defining features of unplanned interrole transitions. Using a convenience sampling method, the author recruited individuals from their personal network and participant referrals. All participants had to meet specific eligibility criteria to ensure they had experienced interruptions at home and could thus provide detailed descriptions of their interruption and interrole transition experiences [53]. First, individuals had to work full-time mainly in a traditional work setting that was physically separate from their homes, but with the flexibility to conduct their work anywhere and anytime via ICTs since ICTs increase availability and response expectations $[4,5,35,54,55]$. Second, individuals were required to regularly interact with others during their workdays (e.g., supervisors, teams, clients; e.g., [47]). To help generalize results, the sample was not restricted to a particular industry, and workers whose experiences with interruptions could be atypical (e.g., small business owners, self-employed, and temporary workers) were excluded. Phase one received research ethics committee (e.g., institutional review board) approval. Participants were recruited from the New York metropolitan area, which was an appropriate region to study since it has been designated as a having one of the highest work stress levels in the United States, based on various criteria including average weekly work hours [56]. Thus, a sample from this particular geographic area could help ensure the recruitment of participants who are likely to experience ICT-related interruptions at home and ICT use during nonwork time.

An email invitation from the author included a general description of the study (a study on how employees' work interacts with personal life), the eligibility requirements (described earlier), and consent form. Individuals who were interested, confirmed eligible, and consented to participate were contacted via email to schedule a phone or in-person interview. During data collection, the author transcribed, verified, and open-coded the data to identify emergent themes. When no new themes emerged, suggesting data saturation [22, 23], recruitment ended, and the remaining scheduled interviews were completed.

A total of 18 eligible participants were interviewed in phase one (see Table 1). The sample included ten women and eight men with an average age of 35-years-old; the majority was white, fourteen participants were married/living as married, and seven had children. Education levels ranged from high school/GED to graduate degree, and job titles and job levels varied. Organizational tenure ranged from less than one year to 29 years (average $=7$ years).

Five semistructured interviews were conducted in person and 13 via telephone. The interview questions were adapted to the described experiences and how much information the participants were able to provide. The interview protocol (see Appendix A) included a general introduction with a description of the types of experiences to be explored in the interviews, open-ended questions to gather detailed descriptions of two recent memorable interruptions at home, questions to probe particular elements of each interruption event, follow-up questions based on how much detail was provided on each interruption, and demographic questions. To ensure participants understood what type of experiences were being explored, examples of planned work during nonwork time and unexpected ICT-related interruptions at home were provided.

The event reconstruction method [57] was utilized to help participants recall interruption experiences. Participants were asked to recall two recent memorable experiences: (1) expected work-related ICT use at home that necessitated a planned interrole transition (e.g., planned conference call), (2) an unexpected ICT-related interruption at home that required an unplanned interrole transition (e.g., an unanticipated phone call from one's boss). ERM helps participants accurately reconstruct details of momentary past events via episodic memory traces [58]. Participants focus on exactly what happened when an event occurred, helping to reactivate behaviors, thoughts, and emotions before, during, and after the event [57]. ERM also helps reduce memory biases [59], which makes it an accurate and refined qualitative approach.

To further ensure the reliability and validity of the data, participants selected their most memorable events from the past few months and answered questions about the specific interruption (timing, location, source, type of ICT, etc.), their underlying thought processes and emotions during the interruption and while responding, their behavioral and emotional responses to the interruption and interrole transition process, and the impact on them [60]. To verify that interruptions at home were indeed perceived as boundary violations, participants rated the extent to which the interruptions were unexpected, intrusive, and urgent (e.g., $1=$ not all intrusive to $7=$ extremely intrusive). To distinguish between planned and unplanned interrole transitions (in response to planned ICT use during nonwork hours vs. unexpected interruptions at home), participants rated the extent to which each interrole transition was disruptive and difficult (e.g., $1=$ not all difficult to $7=$ extremely difficult).

4.2. Phase 1 Content Analysis. An inductive, data-driven approach to content analysis was conducted to identify distinctive features of unexpected ICT-related interruptions at home and associated unplanned interrole transition responses [61]. Content analysis is considered a useful approach to gathering quantifiable information from a qualitative data collection method [62] and for developing a model. After summarizing and outlining the data [63-65], four coding phases were conducted: (1) open-coding, (2) focus coding, (3) axial coding, and (4) full content analysis with the final codes $[23,63,66]$.

Open-coding involves breaking down, examining, comparing, conceptualizing, and categorizing qualitative data [23]. The frequency of themes was compared and contrasted to identify emergent themes that distinguished planned after-hours work from unexpected ICT-related interruptions as well as planned from unplanned interrole transitions. For focus coding, codes were examined to determine their utility 
TABle 1: Phase 1 and phase 2 participants.

\begin{tabular}{|c|c|c|c|c|c|c|c|c|c|}
\hline Participant & Gender & Age & Ethnicity & $\begin{array}{c}\text { Married/ } \\
\text { cohabitating }\end{array}$ & Parent & Education & Job level & $\begin{array}{l}\text { Tenure } \\
\text { (years) }\end{array}$ & Job type/title \\
\hline \multicolumn{10}{|l|}{ Phase 1} \\
\hline 1 & Female & 31 & White & Yes & Yes & $\begin{array}{l}\text { Ph.D. or } \\
\text { other }\end{array}$ & $\begin{array}{l}\text { Nonmanager } \\
\text { professional staff }\end{array}$ & 1 & Psychologist \\
\hline 2 & Female & 30 & White & Yes & No & $\begin{array}{l}\text { Bachelor } \\
\text { degree }\end{array}$ & $\begin{array}{l}\text { Executive (e.g., vice } \\
\text { president) }\end{array}$ & 8 & Marketer \\
\hline 3 & Female & 60 & White & Yes & Yes & $\begin{array}{l}\text { Master } \\
\text { degree }\end{array}$ & $\begin{array}{l}\text { First-level supervisor/ } \\
\text { manager }\end{array}$ & 4 & Medical technician \\
\hline 4 & Female & 31 & White & Yes & No & $\begin{array}{l}\text { Bachelor } \\
\text { degree }\end{array}$ & $\begin{array}{c}\text { Clerical, administrative, } \\
\text { sales staff }\end{array}$ & 5.5 & Executive assistant \\
\hline 5 & Female & 23 & White & No & No & $\begin{array}{l}\text { Master } \\
\text { degree }\end{array}$ & $\begin{array}{c}\text { Nonmanager } \\
\text { professional staff }\end{array}$ & 1 & Accountant \\
\hline 6 & Male & 29 & White & Yes & No & $\begin{array}{l}\text { Some } \\
\text { college }\end{array}$ & Senior manager & 12 & Sales manager \\
\hline 7 & Male & 30 & White & Yes & No & $\begin{array}{l}\text { Bachelor } \\
\text { degree }\end{array}$ & Midlevel manager & 4.5 & Accountant \\
\hline 8 & Female & 50 & Black & Yes & Yes & $\begin{array}{l}\text { Bachelor } \\
\text { degree }\end{array}$ & Senior manager & 29 & Clerical manager \\
\hline 9 & Male & 34 & White & Yes & Yes & $\begin{array}{l}\text { Bachelor } \\
\text { degree }\end{array}$ & $\begin{array}{c}\text { First-level supervisor/ } \\
\text { manager }\end{array}$ & 5.5 & $\begin{array}{c}\text { Telecommunications } \\
\text { supervisor }\end{array}$ \\
\hline 10 & Female & 23 & Black & No & No & $\begin{array}{l}\text { Bachelor } \\
\text { degree }\end{array}$ & $\begin{array}{l}\text { First-level supervisor/ } \\
\text { manager }\end{array}$ & 1 & Office manager \\
\hline 11 & Male & 30 & White & Yes & No & $\begin{array}{l}\text { Master } \\
\text { degree }\end{array}$ & $\begin{array}{c}\text { Nonmanager } \\
\text { professional staff }\end{array}$ & 2.5 & $\begin{array}{c}\text { Human resource } \\
\text { professional }\end{array}$ \\
\hline 12 & Female & 34 & White & Yes & Yes & $\begin{array}{l}\text { Master } \\
\text { degree }\end{array}$ & Midlevel manager & 8 & College instructor \\
\hline 13 & Male & 36 & White & Yes & Yes & $\begin{array}{l}\text { Master } \\
\text { degree }\end{array}$ & $\begin{array}{c}\text { Director (e.g., } \\
\text { department head) }\end{array}$ & 5 & Finance manager \\
\hline 14 & Female & 30 & Black & Yes & No & $\begin{array}{l}\text { Bachelor } \\
\text { degree }\end{array}$ & $\begin{array}{c}\text { Director (e.g., } \\
\text { department head) }\end{array}$ & 5 & Technology director \\
\hline 15 & Male & 55 & White & Yes & Yes & $\begin{array}{l}\text { Some } \\
\text { college }\end{array}$ & $\begin{array}{c}\text { Director (e.g., } \\
\text { department head) }\end{array}$ & 12 & Project director \\
\hline 16 & Female & 39 & Hispanic & No & Yes & $\begin{array}{l}\text { Some } \\
\text { college }\end{array}$ & $\begin{array}{c}\text { Director (e.g., } \\
\text { department head) }\end{array}$ & 9 & Client director \\
\hline 17 & Male & 23 & White & No & No & $\begin{array}{c}\text { Bachelor } \\
\text { degree }\end{array}$ & $\begin{array}{c}\text { Nonmanager } \\
\text { professional staff }\end{array}$ & 1 & Engineer \\
\hline 18 & Male & 34 & Hispanic & Yes & No & $\begin{array}{l}\text { Bachelor } \\
\text { degree }\end{array}$ & $\begin{array}{c}\text { Nonmanager } \\
\text { professional staff }\end{array}$ & 4 & Engineer \\
\hline \multicolumn{10}{|l|}{ Phase 2} \\
\hline 1 & Female & 29 & White & Yes & No & $\begin{array}{l}\text { Bachelor } \\
\text { degree }\end{array}$ & Midlevel manager & $<1$ & Financial analyst \\
\hline 2 & Female & 33 & White & Yes & Yes & $\begin{array}{l}\text { Master } \\
\text { degree }\end{array}$ & Midlevel manager & 4 & Logistics manager \\
\hline 3 & Male & 30 & White & Yes & No & $\begin{array}{l}\text { Bachelor } \\
\text { degree }\end{array}$ & Midlevel manager & 6 & Real estate sales \\
\hline 4 & Female & 33 & White & Yes & Yes & $\begin{array}{l}\text { Master } \\
\text { degree }\end{array}$ & Senior manager & $<1$ & Banking \\
\hline 5 & Female & 31 & White & Yes & Yes & $\begin{array}{l}\text { Ph.D. or } \\
\text { other }\end{array}$ & $\begin{array}{c}\text { Nonmanager } \\
\text { professional staff }\end{array}$ & 3.5 & Lawyer \\
\hline 6 & Female & 32 & Asian & Yes & No & $\begin{array}{l}\text { Ph.D. or } \\
\text { other }\end{array}$ & $\begin{array}{c}\text { Nonmanager } \\
\text { professional staff }\end{array}$ & 1.5 & School psychologist \\
\hline 7 & Female & 29 & White & No & No & $\begin{array}{l}\text { Master } \\
\text { degree }\end{array}$ & $\begin{array}{c}\text { Nonmanager } \\
\text { professional staff }\end{array}$ & 5 & Social worker \\
\hline
\end{tabular}


TABLE 1: Continued.

\begin{tabular}{|c|c|c|c|c|c|c|c|c|c|}
\hline Participant & Gender & Age & Ethnicity & $\begin{array}{c}\text { Married/ } \\
\text { cohabitating }\end{array}$ & Parent & Education & Job level & $\begin{array}{l}\text { Tenure } \\
\text { (years) }\end{array}$ & Job type/title \\
\hline 8 & Male & 42 & White & Yes & Yes & $\begin{array}{l}\text { Some } \\
\text { college }\end{array}$ & Midlevel manager & 3 & Hotel management \\
\hline 9 & Female & 36 & White & No & No & $\begin{array}{l}\text { Master } \\
\text { degree }\end{array}$ & Midlevel manager & 12 & Financial aid manager \\
\hline 10 & Female & 36 & White & No & No & $\begin{array}{l}\text { Master } \\
\text { degree }\end{array}$ & $\begin{array}{c}\text { First-level supervisor/ } \\
\text { manager }\end{array}$ & 4 & $\begin{array}{c}\text { Organizational } \\
\text { psychologist }\end{array}$ \\
\hline 11 & Male & 32 & White & Yes & No & $\begin{array}{l}\text { Master } \\
\text { degree }\end{array}$ & $\begin{array}{c}\text { Nonmanager } \\
\text { professional staff }\end{array}$ & 2 & Consultant \\
\hline 12 & Female & 55 & White & No & Yes & $\begin{array}{r}\text { Master } \\
\text { degree }\end{array}$ & $\begin{array}{c}\text { Director (e.g., } \\
\text { department head) }\end{array}$ & 1 & Nursing director \\
\hline 13 & Male & 33 & White & Yes & Yes & $\begin{array}{r}\text { Master } \\
\text { degree }\end{array}$ & $\begin{array}{l}\text { Nonmanager } \\
\text { professional staff }\end{array}$ & 4.5 & Data analyst \\
\hline 14 & Female & 62 & White & Yes & Yes & $\begin{array}{r}\text { Master } \\
\text { degree }\end{array}$ & $\begin{array}{c}\text { Nonmanager } \\
\text { professional staff }\end{array}$ & 24 & Music therapist \\
\hline 15 & Female & 32 & Asian & No & No & $\begin{array}{l}\text { Master } \\
\text { degree }\end{array}$ & $\begin{array}{c}\text { Nonmanager } \\
\text { professional staff }\end{array}$ & 1 & Therapist \\
\hline 16 & Male & 55 & White & Yes & No & $\begin{array}{l}\text { Master } \\
\text { degree }\end{array}$ & $\begin{array}{c}\text { Nonmanager } \\
\text { professional staff }\end{array}$ & 19 & Financial advisor \\
\hline 17 & Female & 40 & White & Yes & Yes & $\begin{array}{l}\text { Master } \\
\text { degree }\end{array}$ & Senior manager & 2 & Fundraising manager \\
\hline 18 & Male & 38 & White & Yes & Yes & $\begin{array}{l}\text { Master } \\
\text { degree }\end{array}$ & Senior manager & 4 & Financial analyst \\
\hline 19 & Female & 64 & White & Yes & Yes & $\begin{array}{l}\text { Ph.D. or } \\
\text { other }\end{array}$ & $\begin{array}{c}\text { Nonmanager } \\
\text { professional staff }\end{array}$ & 12 & College instructor \\
\hline
\end{tabular}

and thus helped ensure maximized differentiation between experiences $[63,66]$. The number of times a preliminary theme was present in the subsample of data was noted, infrequent codes were eliminated, redundant codes were collapsed, and vague codes were elaborated upon.

Axial coding involves grouping data together using a paradigm [23]. The paradigm was based on the following features of unexpected ICT-related interruptions at home and unplanned interrole transitions that emerged from prior coding stages: context (e.g., timing), causal conditions (e.g., reason for interruptions), interruption characteristics (e.g., source, content), interrole transition characteristics (e.g., duration), underlying conditions of interrole transitions (e.g., reasons for responding), transition process actions, and outcomes (e.g., thoughts and feelings afterward). A subject matter expert reviewed the data and themes to confirm accurate representation of participant experiences [67]. Also, a participant cross-check was conducted where some participants confirmed that the codes adequately captured their experiences [68].

Next, a trained undergraduate research assistant (RA) and the author independently applied the codes to three transcripts, and then the degree of consistency (i.e., agreement) in judgments was calculated. The first interrater reliability (IRR) score (i.e., percent of agreement) was $79 \%$. Discrepancies were discussed and resolved, and no codes were dropped as a result, but some code definitions were refined. Based on two additional rounds of IRR, the final score was $92 \%$, which was considered acceptable. Using a spreadsheet to code all data, if a participant's response related to a code, a "1" was noted, which allowed the summing of codes and calculation of code frequencies across participants. Multiple codes could be applied to an episode.

4.3. Phase 1 Results. Participant ratings verified that the reported ICT-related interruptions from work at home were unexpected $(M=5.67, \mathrm{SD}=1.46)$, intrusive $(M=6.17, \mathrm{SD}$ $=0.92)$, and urgent $(M=6.17, \mathrm{SD}=1.54)$. Participant ratings of interrole transition responses verified that unplanned interrole transitions were more problematic than planned interrole transitions, with unplanned transitions rated as more disruptive than unplanned transitions $(M=5.33$ and $M=3.89$, respectively; $t(17)=-5.11, p<.001)$ and more difficult $(M=4.89$ and $M=4.00$, respectively; $t(17)=-2.12$, $p<.05)$.

With respect to identifying the central characteristics of interruptions at home (RQ1), the codes within the following HOCs were examined: context, underlying conditions, causal conditions, and characteristics. Based on the HOCs, the most dominant features of interruptions were their occurrence, predictability, legitimacy, underlying affect, and interference extent. More specifically, interruptions were most frequently characterized as rare $(72 \%)$, unpredictable $(61 \%)$, and legitimate $(67 \%)$, as well as causing negative affect (94\%) and interference with personal life (94\%).

Phase one was also designed to reveal the defining features and underlying mechanisms of unplanned interrole transition in response to interruptions (RQ2). After 
comparing the causal conditions, underlying conditions, characteristics, and outcomes of planned vs. unplanned transitions, codes were developed for the defining features of unplanned interrole transitions. Causal conditions included the underlying motivations for transitions, e.g., participants were likely to engage in unplanned transitions because of pressure (internal and external) and expectations. Underlying conditions helped identify the following fundamental qualities of unplanned interrole transitions: transition type (behavioral or psychological), requirements (immediate and follow-up), and duration. As expected, unplanned transitions mainly required behavioral work tasks to be completed via ICTs (e.g., investigate a customer complaint with follow-up calls), and some required additional time-consuming mental and behavioral tasks (e.g., preparing for next day, gathering information). The defining characteristics of unplanned transitions were the extent and duration of interference, difficulty, and negativity. Specifically, unplanned transitions were characterized as time consuming $(83 \%)$, creating feelings of work-family interference $(78 \%)$, preventing work detachment $(39 \%)$, mentally and physically challenging ( $83 \%$ and $50 \%$, respectively), and engendering negative emotions (94\%) which provoked negative attitudes (94\%).

Phase one findings suggested components of the process to explore more deeply in phase two. For instance, incidents did not definitively end after an immediate behavioral response (e.g., email reply), with $67 \%$ of interrole transition experiences requiring follow-up work that lasted an hour or more. This additional work also had a lasting psychological impact on individuals in the form of time sinks and cognitive shifts that lasted the rest of the day (44\%) and even spilling into the next day or more (28\%), for example:

"The mental disruption was longer than that...mentally, you find yourself distracted for the rest of the evening. What's gonna happen with this, and your thoughts, constantly, keep drifting back towards work, what are the outcomes, you think about all the possible outcomes, what's gonna happen on Monday morning...did I do the right thing with the customer, are they gonna go with me with my particular proposal, was I right in line...it takes a little while to get to bed".

Additionally, results suggest that employee appraisals were important, particularly influencing their reactions to interruptions. For example, responses seemed warranted for legitimate interruptions at home (e.g., $61 \%$ of participants stated a response was justified when co-workers were relying on them), for example:

"I knew he called me because he finds me to be one of the more dependable managers and he would have been disappointed. If I didn't go in then no other manager would go so I felt that I should do it".

4.4. Phase 2 Sample and Procedures. Phase two was designed to clarify the underlying and linking mechanisms of the stimulus (i.e., interruption) and response (i.e., interrole transition) to aid in the development of a data-driven episodic process model with testable propositions. The same sample criteria from phase one were applied in phase two to help ensure participants could share details of specific ICTrelated interruptions at home and associated interrole transition responses. Phase two also received research ethics committee (e.g., institutional review board) approval.

Participants were recruited throughout the United States on several web-based social networking websites with a convenience sampling approach. A description of the study and sample criteria were posted and interested individuals emailed the author for more details. If they were still interested, they completed a screening survey with demographic questions to verify whether they met the sample criteria (identical to phase one). Next, eligible participants were asked to sign a consent form and then contacted again via email to schedule a phone interview with the author. Similar to phase one, during data collection the data were transcribed, verified, and open-coded to identify emergent themes. When no new themes emerged, recruitment ended and the remaining scheduled interviews were completed $(N=19)$.

Participants (see Table 1) included 13 women and 6 men with an average age of 40 years old; the majority was white, 15 participants were married/living as married, and eleven had children. Education levels ranged from some college to graduate degrees, and job levels and job titles varied. Organizational tenure ranged from less than one year to 24 years ( $M=6$ years).

To achieve data saturation [22, 23], 32 events were explored in-depth using ERM [57]. In contrast to phase one, phase two interviews focused only on unexpected ICT-related interruptions at home to ensure the phenomenon of interest was fully captured (see Appendix B for the full interview guide). Some interview questions were derived from phase one HOCs and themes, and additional questions were added to ensure identification of all aspects of the interruption-response experience. For each interruption, participants described (1) why they reacted and responded in the way they did, 2) all interrole transition responses (immediate and follow-up), and (3) short-term and longterm inner thoughts and feelings (e.g., "What were you thinking at the time," "Looking back, how do you feel about the experience?"). Similar to phase one, ERM helped to uncover behavioral, cognitive, and emotional information that was not directly observable.

4.5. Phase 2 Content Analysis. Following the phase one approach, an inductive and data-driven approach to content analysis was conducted [61]. As discussed in the phase one section, content analysis is useful for developing a model with propositions. Various rounds of coding were conducted with subsamples of data to derive the process model. Although phase one provided initial HOCs and themes, emergent HOCs and themes/codes were developed based on phase two content analysis.

First, based on open-coding of a subsample of events $(n=8)$, an initial codebook was developed with HOCs, sub-categories, themes, and codes. The codebook was revised based on pilot tests with trained undergraduate RA using another subsample of data $(n=6)$. Then, the author and a trained graduate RA conducted four rounds of IRR based on another subsample of events $(n=8$, with two 
interviews coded in each round). The IRR for each round was $82 \%, 83 \%, 88 \%$, and $90 \%$, respectively. Based on this process, some revisions were made to the codebook.

Next, aside from the contextual HOCs (e.g., perceived organizational support), themes were organized into stages (interruption, interruption reaction, interrole transition, transition reaction, short, and long-term outcomes) to capture the process. To ensure the model was fully specified, the author and graduate RA applied the themes/codes, organized by stage, to another subsample $(n=6)$ and discussed the coding. Some new components were added and some existing components revised. Then, it was agreed that no new information was being added by the data.

The final codebook was applied to all 19 interviews (and 32 events) by the author and graduate RA, with ongoing discussions. Applicable codes were indicated with a " 1 " which allowed the summing of codes and calculation of percentages across participants to determine the proportion of events related to each theme/code (see Table 2). Based on the final coding round, no revisions were made to the codebook, providing some evidence for "theoretical saturation" [69] and verifying that the model was fully developed.

4.6. Phase 2 Results. The goal of phase two content analysis was to clarify the interrelated underlying mechanisms and outcomes of the process (research questions 3 and 4). Then, data from phases one and two were combined to develop an episodic process model grounded in data with testable propositions. It was appropriate to combine phase one and two samples, as identical criteria were used to recruit participants for each phase, and the samples were comparable in terms of key demographics (gender, age, marital status, parental status, education, organizational tenure, and diversity of job levels and job titles). The average age and tenure of participants did not significantly differ between the samples $(t(35)=-1.25 ; p=0.218$ and $t(35)=0.369 ; p=0.715)$. There were also no significant differences across the samples in the proportion of women $\left(\chi^{2}(1, N=37)=0.65, p=\right.$ $0.420)$, white participants $\left(\chi^{2}(1, N=37)=1.79, p=0.181\right)$, married participants $\left(\chi^{2}(1, N=37)=0.08, p=0.772\right)$, parents $\left(\chi^{2}(1, N=37)=2.48, p=0.618\right)$, college-educated participants $\left(\chi^{2}(1, N=37)=1.25, p=0.264\right)$, or managers $\left(\chi^{2}(1, N=37)=0.755, p=0.385\right)$.

The HOCs, themes, and codes were organized into six stages of the process model (see Figure 1): (1) context, (2) interruption (i.e., stimulus), (3) immediate response (appraisals and reactions), and (4) interrole transition response (underlying conditions, characteristics, appraisals, reactions), episodic outcomes (for work and nonwork), and long-term outcomes (for work and nonwork). Based on the highest code percentages, the most prominent themes were incorporated into each stage of the model. For example, interruption timing, message content, and message tone were prominent themes and thus included in the model as critical characteristics.

4.6.1. An Episodic Process Model. The dynamic process model has various appraisal stages that drive further appraisals, reactions, responses, and outcomes. The model illustrates that (1) contextual variables influence the process, (2) episodes go beyond a stimulus-response process, (3) the interrole transition is a complex and distinct stage of the process, (4) appraisals and reactions occur at various stages and influence subsequent stages, and (5) there are short and long-term effects. Next, each proposition is explained and supported with quotes.

4.6.2. Propositions $1 a$ and $1 b$ : Context and Interruptions. Work-family contextual variables are expected to influence immediate responses to ICT-related interruptions at home and interrole transitions (P1a and P1b). For example, the extent to which boundary preferences align with actual boundary management strategies is expected to influence how interruptions are appraised. The following comment illustrates how the boundary management preferences and strategies of a female attorney influenced her appraisals and reactions to an email interruption as well as her decision to respond (i.e., interrole transition):

"...if I'm on vacation with my kids and with my husband and we're visiting family and we travelled a long way to get there, it's not as though I could just say, 'everybody leave me alone, I'm sitting down at the computer until this is done' ...that's not something I was willing to do...I take one week vacation a year. I work a lot. I don't get that time with my family, you know like that solid vacation time away from everything, just time together. So you know I was not going to say to my kids, who were also little, 'leave me alone, I have to do this for work' and it would take a day. It was my unwillingness to do that, and [deal with] the technological issues, and I'm only one in contact with this guy...”.

4.6.3. Propositions 2-4: Immediate Responses to Interruptions. The results also suggested that ICT-related interruption characteristics (timing, tone, and message content) affect immediate responses (appraisals and reactions), with the predictability and legitimacy of both the interruption itself and the work-related message as critical. The proposed chain of events is such that interruption characteristics (e.g., timing of incident) influence appraisals (e.g., its predictability; P2), which then influence affective reactions (P3). At the same time, appraisal of the work-related message (e.g., legitimacy of the issue presented in a workrelated email) seems to influences affective reactions to the message (P4). The following comments illustrate how interruption characteristics (timing and tone of sender) influence immediate responses (P2):

“...And I got this nasty email from my boss saying like we missed all this stuff we need to do better at like 4:30 on Thursday before July 4th which isn't kind of how you want to roll into the long weekend...he'll get negative feedback from his boss and it kind of just rolls downhill... he certainly doesn't make a point of sending emails like that ya know at times like that... it was just more like the fact that he couldn't have waited until Monday morning to have the conversation. I just thought that was kind of rude...".

“... one of the deal team members sent me back an email saying in effect 'it sounds like you characterized things inappropriately to the client and if you keep doing that I'm going 
TABLE 2: Phase two higher-order categories, themes, and code frequencies for ICT-related interruptions at home and interrole transition responses.

\begin{tabular}{|c|c|c|c|c|}
\hline Higher-order categories & Subcategories & Theme & Code & $N$ \\
\hline \multirow{6}{*}{$\begin{array}{l}\text { Work-family contextual } \\
\text { variables }\end{array}$} & & & Value alignment & 13 \\
\hline & Boundary preferences and strategy & Alignment & Incongruent with values & 3 \\
\hline & \multirow{4}{*}{ Perceived organizational support } & \multirow{4}{*}{$\begin{array}{l}\text { Support for work-life } \\
\text { balance }\end{array}$} & Not sure/it depends & 3 \\
\hline & & & Supported & 11 \\
\hline & & & Not sure/it depends & 5 \\
\hline & & & Unsupported & 3 \\
\hline \multirow{9}{*}{ Interruption characteristics } & \multirow{2}{*}{ Timing } & \multirow{2}{*}{ Type of day } & Weekend/vacation/holiday & 18 \\
\hline & & & Weekday/work day & 14 \\
\hline & \multirow{4}{*}{ Message content } & \multirow{2}{*}{ Problem/issue } & Work-related problem-internal & 17 \\
\hline & & & Work-related problem-external & 5 \\
\hline & & \multirow{2}{*}{ Not an issue } & Update/informational & 8 \\
\hline & & & Question/help & 2 \\
\hline & \multirow{3}{*}{ Message tone } & \multirow{3}{*}{ Tone of sender } & Neutral & 17 \\
\hline & & & Negative & 14 \\
\hline & & & Positive & 1 \\
\hline \multirow{21}{*}{$\begin{array}{l}\text { Interruption appraisal } \\
\text { and reaction }\end{array}$} & \multirow{6}{*}{ Appraisal of interruption } & \multirow{2}{*}{ Predictability } & Routine & 24 \\
\hline & & & Unexpected & 8 \\
\hline & & & Necessary/made sense & 24 \\
\hline & & Legitimacy_necessary & $\begin{array}{l}\text { Unnecessary/did not make any } \\
\text { sense }\end{array}$ & 8 \\
\hline & & Ieritimecy renconoble & Reasonable/fair & 28 \\
\hline & & Legitimacy-ieasonadie & Unreasonable/unfair & 4 \\
\hline & \multirow{3}{*}{ Reaction to interruption } & \multirow{3}{*}{ Affect } & Neutral & 21 \\
\hline & & & Negative & 10 \\
\hline & & & Positive & 1 \\
\hline & \multirow{7}{*}{ Message appraisal } & \multirow{3}{*}{ Legitimacy_significant } & Important (but not a crisis) & 19 \\
\hline & & & Crisis & 9 \\
\hline & & & Insignificant & 4 \\
\hline & & \multirow{2}{*}{ Predictability-expected } & Unexpected & 19 \\
\hline & & & Expected & 13 \\
\hline & & \multirow{2}{*}{ Predictability-common } & Unusual & 16 \\
\hline & & & Routine & 13 \\
\hline & \multirow{5}{*}{ Message reaction } & \multirow{3}{*}{ Affect } & Negative & 20 \\
\hline & & & Neutral & 10 \\
\hline & & & Positive & 2 \\
\hline & & \multirow{2}{*}{ Rumination } & Rumination-no & 18 \\
\hline & & & Rumination-yes & 14 \\
\hline & Recnonce eynectancy & & Yes & 25 \\
\hline & Kesponse expectancy & & No & 7 \\
\hline & & & Immediate & 24 \\
\hline & Response time & & Delayed & 4 \\
\hline Interrole transition & & & Ignored/did not respond & 4 \\
\hline underlying conditions & & Intamamonel nnogre & Internal pressure & 14 \\
\hline & & Interpersonal pressure & External pressure & 10 \\
\hline & Response motivation & Time preccure & Required immediate response & 19 \\
\hline & & 1ilite piessure & Urgent matter & 17 \\
\hline & & Job expectations & Part of job description & 21 \\
\hline
\end{tabular}


TABle 2: Continued.

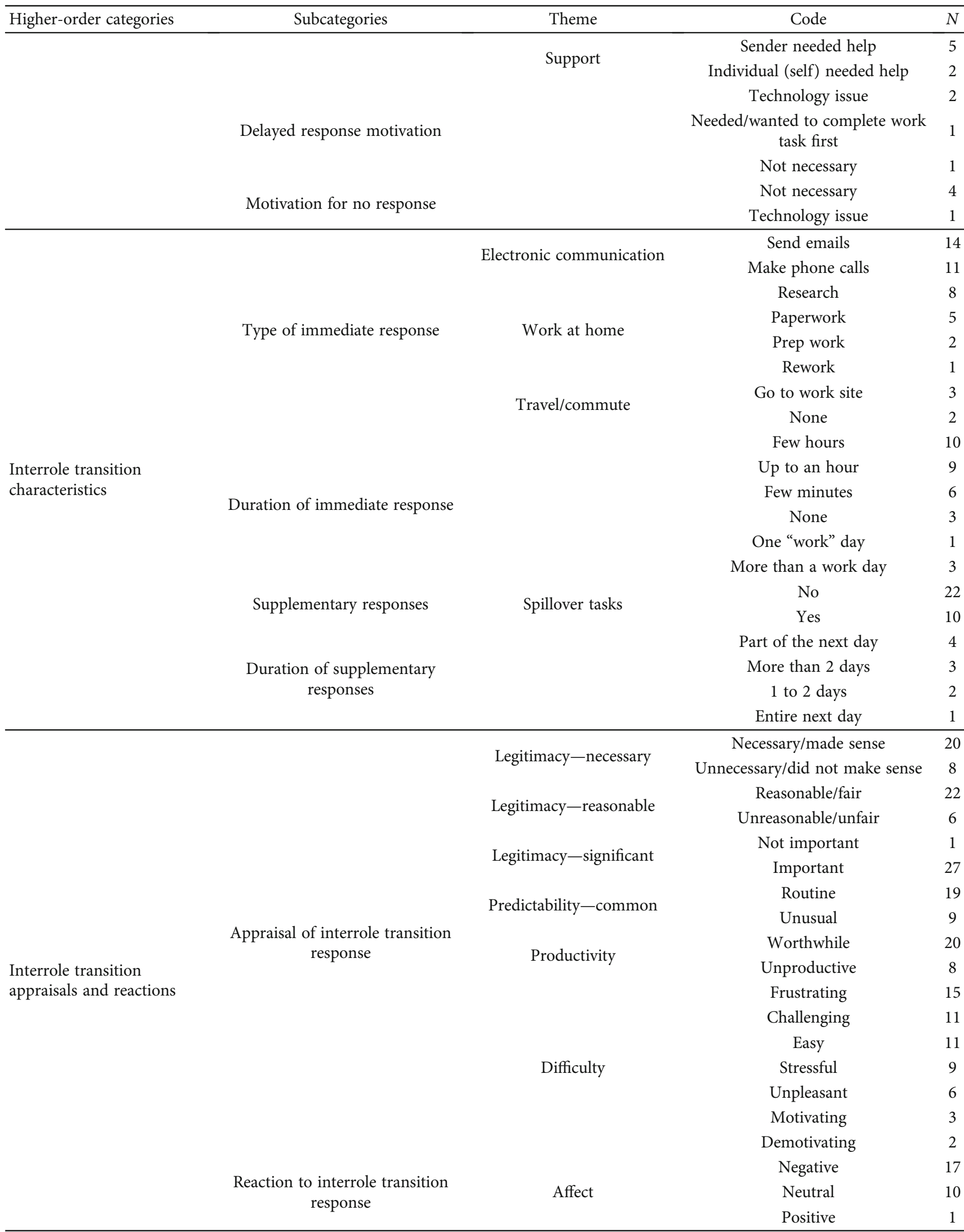


TABLE 2: Continued.

\begin{tabular}{|c|c|c|c|c|}
\hline Higher-order categories & Subcategories & Theme & Code & $N$ \\
\hline \multirow{16}{*}{ Episodic outcomes } & \multirow{8}{*}{ Work outcomes } & \multirow{2}{*}{ Task resolution } & Resolved & 21 \\
\hline & & & Unresolved & 7 \\
\hline & & \multirow{2}{*}{ Task effect } & Improved situation for other & 8 \\
\hline & & & Improved situation for self & 2 \\
\hline & & \multirow{2}{*}{ Interference-time-based } & Timing was inconvenient & 16 \\
\hline & & & Timing was insignificant & 12 \\
\hline & & \multirow{2}{*}{$\begin{array}{l}\text { Interference-behavior- } \\
\text { based }\end{array}$} & $\begin{array}{l}\text { Disruptive to nonwork task/ } \\
\text { activities }\end{array}$ & 20 \\
\hline & & & $\begin{array}{c}\text { Not disruptive to nonwork tasks/ } \\
\text { activities }\end{array}$ & 8 \\
\hline & \multirow{8}{*}{ Work-to-nonwork outcomes } & \multirow{3}{*}{ Interference-strain-based } & Reduced stress & 9 \\
\hline & & & Overloaded/work-to-life conflict & 7 \\
\hline & & & Increased stress & 3 \\
\hline & & \multirow{2}{*}{$\begin{array}{c}\text { Lack of psychological } \\
\text { detachment }\end{array}$} & Rumination-yes & 12 \\
\hline & & & Rumination-no & 16 \\
\hline & & \multirow{3}{*}{$\begin{array}{l}\text { Interference-emotion- } \\
\text { based }\end{array}$} & Negative & 13 \\
\hline & & & Neutral & 12 \\
\hline & & & Positive & 3 \\
\hline \multirow{6}{*}{ Long-term outcomes } & \multirow{3}{*}{ Work outcomes } & & Mixed or neutral & 15 \\
\hline & & & Positive & 11 \\
\hline & & & Negative & 8 \\
\hline & \multirow{3}{*}{ Work-to-nonwork outcomes } & & Mixed (ambivalence) & 19 \\
\hline & & & Negative (interference) & 11 \\
\hline & & & Positive (enrichment) & 3 \\
\hline
\end{tabular}

Note. For work-family contextual variables, codes were applied at person-level $(N=19)$. For interruption characteristics, appraisals and reactions, and for response expectancy and response time, codes were applied at episode-level $(N=32)$, but only one code per theme could be applied to an episode. For response motivation and type, codes were not applicable to all episodes and multiple codes from each theme could be applied. For response duration, codes were applied at episode-level $(N=32)$, but only one code per theme could be applied. For duration of supplementary responses, codes were applied only to supplementary interrole transitions $(n=10)$ and only one code per theme could be applied to an episode. For interrole transition response appraisals and reactions and for episodic outcomes, codes were applied only to immediate/delayed interrole transitions $(n=28)$ and only one code per theme could be applied. For long-term outcomes, codes were applied to all episodes $(N=32)$ and multiple codes could be applied.

to tell your boss' kind of thing so it really was sort of a flame... and in my view very inappropriate. So that was very emotional circumstance where somebody is calling me out on an email...it was annoying emotionally...”.

The next comments illustrate how appraisals of interruptions-the predictability and legitimacy specifically-seem to influence affective reactions to interruptions (P3):

“...when I come home if I'm expecting it then I sort of map it out myself, but not having expected it I guess my anxiety sort of increased and it sort of just throws you off...”.

"...on Friday night you are just coming off the work week...it wasn't a pleasant email to get even if on a Wednesday at two o'clock. But at least is would have been relevant".

"... The fact that he sent it when I really didn't want to be reading email. And there may have been another person who wouldn't have checked their email and wouldn't have seen it until Monday. But he knows that I would... the fact that he would send a negative email now, at a time when he knows I'm probably enjoying my weekend, and he knows I will check my email. It just seems very inconsiderate. I had a glass of wine because I just needed to relax. It got me so wound up. It was just very frustrating".
The following comments demonstrate how appraisals of work-related messages-the predictability and legitimacy specifically-may influence affective reactions to messages (P4):

"Her text was...very gracious in that, 'I am really sorry to do this and bother you. I am just really desperate', so part of my emotion was that I felt like I let her down".

"I felt extremely uncomfortable...I didn't agree with his response to what I had sent him. I felt like, in order to try to defend myself, I should have responded; but...I didn't want to say anything that I would regret. Also, I kind of didn't want to give him the day".

"...the first thought is, oh God, what is this...you know obviously they are forwarding me something that was filed in one of your biggest cases, it could be anything. But I was relieved it was something that could be fairly simple for me to read through and it wouldn't take me that long to do. The first thing I thought was dread".

"It's almost like, ignorance is bliss. I would prefer to just not know cause there's nothing I can do and there's nothing that needed to be done until I got back... with the way that the timing worked out, I would have ample time to deal with 


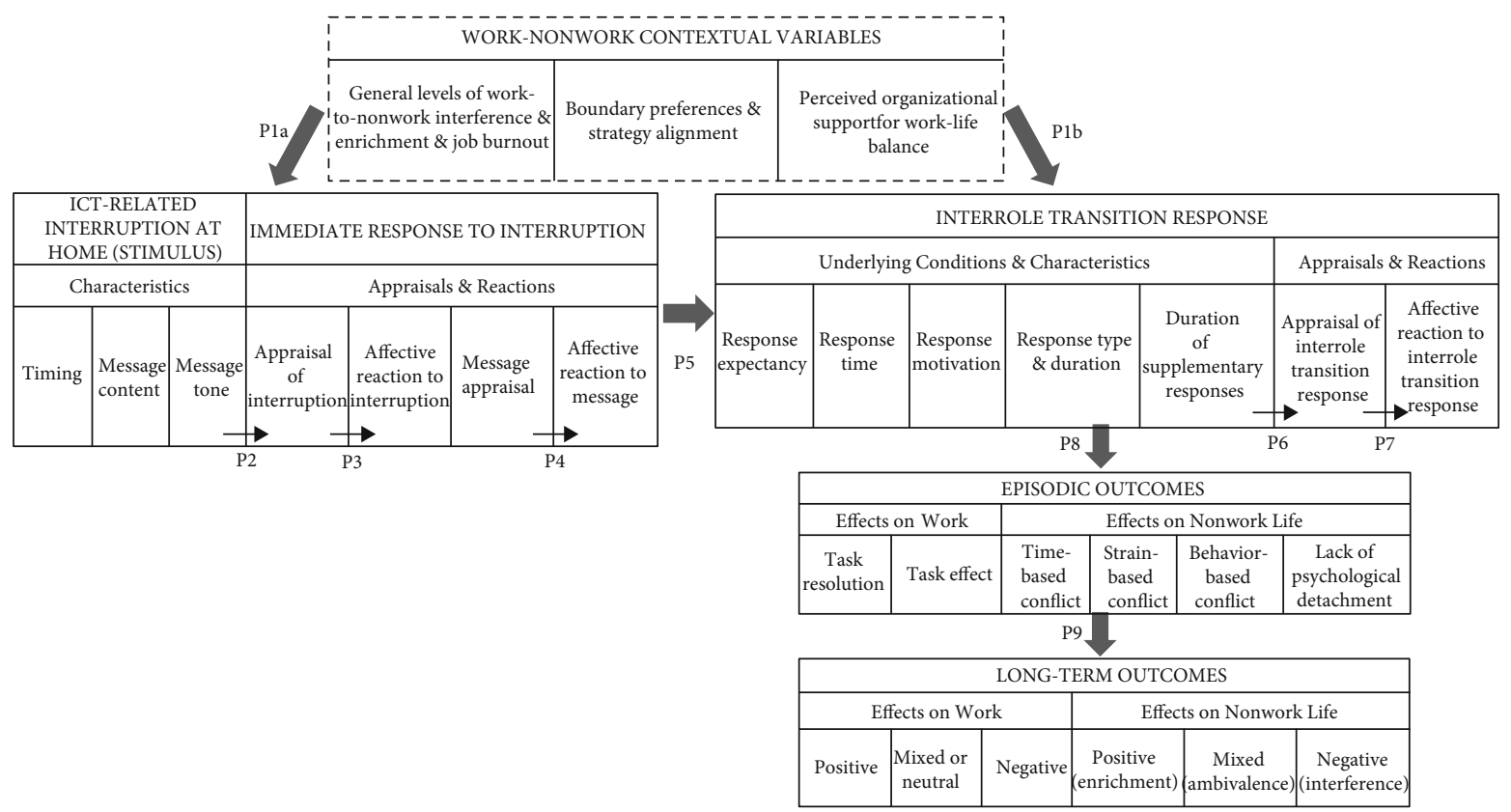

FIgURE 1: Episodic process model of ICT-related interruptions at home and interrole transition responses.

it when I got back. It wasn't an emergency...I would prefer if I could not just not deal with it until... Monday morning... knowing about it, there was no benefit to knowing about it that I don't see".

4.6.4. Propositions 5-7: The Unplanned Interrole Transition Process. Based on the content analysis results, ICT-related interruption characteristics and immediate responses (appraisals and reactions) are expected to influence unplanned interrole transitions (P5), which includes the following underlying conditions and characteristics: response expectancy (i.e., extent to which a response is expected), response time (i.e., how quickly individual responds), interrole transition motivation (i.e., why individual responses), and type and duration of immediate and supplementary (i.e., additional) transitions. These conditions and characteristics are posited to influence appraisals of the interrole transition experience (P6), including the extent to which the transition is deemed as legitimate, predictable, a productive use of one's time, and mentally/emotionally difficult. Together, these appraisals may determine affective reactions to interrole transition experiences (P7). The following comments demonstrate how appraisals of interruptions and messages-the legitimacy and predictability of both-may influence decisions to respond (P5):

"...But she was, she really wanted to get this done and I could tell and I when I can help it I like to not have somebody upset at me or somebody not to sort of have that bad blood, so if I can get it done and just sort of put their mind at ease...".

"...I thought about responding because I would typically respond to an email if I had a response. But since I was so fed up, I didn't respond... Because I was upset by it, I didn't want to say anything out of anger. I wanted to talk to my manager about it, get her thoughts. I just figured that right then wasn't the right time. The same way him sending that email at that time wasn't the right time, it wasn't the right time to respond".

“...Her text... was very gracious in that, 'I am really sorry to do this and bother you. I am just really desperate'...So I had to respond in that moment...I felt very compelled to respond to her...I didn't have a good answer during the business day...I never assumed that she would reach out to me at eleven thirty on a weekday. My compulsion to answer her and my anxiety was because I also knew this kid's family situation...".

The next set of comments exemplify how the underlying conditions and characteristics of interrole transitions (e.g., response timing, response duration, and extent of additional transitions) may influence appraisals of the experience (e.g., extent to which transitions are considered difficult and a productive use of time) and affective reactions (P6 and P7):

"Last summer I spent a week in Northern Michigan...I have very bad cell phone reception...the only way really to connect is to turn on all that stuff and hook up to the internet...And there was a work issue that came to a head while I was away. And that consumed a couple of days. And it was very frustrating. It was something that I could not even work out from where I was. It was a high stress situation, and it was just really horrible timing. It happened while I was in the middle of a vacation, and it was, I couldn't even, being somewhere where I didn't have cell phone reception and there was no house phone, you know I couldn't even pick up my phone call the other attorneys involved, talk to them. You know [inaudible] voicemails. It was really frustrating and really stressful".

"It was probably a solid hour... and then probably a little bit of back and forth over the weekend because we were still trying to figure like are we getting close enough, are we not quite there yet? And then in the end we ended up moving the meeting anyway". 
“...we had a really, really, really egregious mistake from the vendor two days before Thanksgiving...But, we had something happen that was so bad that we had to get two senior vice presidents and an executive vice president on a conference call on the Wednesday afternoon before Thanksgiving. So I mean it was a huge stress on me, but it was also like I've never had to call an EVP on a holiday and say I need an emergency conference call because something didn't work with our project. So it was stressful from a personal angle but it was also very stressful from a professional angle because obviously you don't ever like to go to an executive because you have a problem. So, in the past year and a half I would probably say that that was the most significant and that just consumed the week, I mean there was no Thanksgiving this year...”.

4.6.5. Propositions 8 and 9: Outcomes of Interrole Transitions. The content analysis results also suggested that the interrole transition stage (underlying conditions, characteristics, appraisals, and reactions) influences immediate outcomes (P8). These episodic outcomes include the following effects on work: task resolution (i.e., whether issue was resolved or not) and the effects of conducting extra work on self and others. The episodic outcomes also include the following effects on nonwork life: extent of work-to-family interference and the ability to psychologically detach from work during nonwork hours. Work-tofamily inference was experienced as time-based, strainbased, or behavior-based conflict. Time-based conflict mainly consisted of interrole transitions occurring during inconvenient times (e.g., a special family dinner), strainbased conflict mainly occurred when interrole transitions made individuals feel too drained for nonwork activities, and behavior-based conflict generally occurred when interrole transitions required individuals to engage in work behaviors (e.g., problem solving) that were incompatible with what they were doing at the time (e.g., attending a child's birthday party).

Several comments showed how interrole transitions may affect individuals in the short-term. This first comment shows how the amount of time a consultant spent role transitioning combined with the low difficulty of the experience (because of team collaboration) led to a positive work outcome for his client:

"I think overall it was a positive experience. I mean everyone worked together to get it done. Um, ya know the customer was very happy which is always what you're shooting for. And the people at work were very happy. So, ya know it was frustrating for a few hours but in the end it was certainly more positive than negative".

These comments demonstrate how individuals were able to detach from work after feeling that interrole transitions were productive, even after immediate negative reactions:

"...I got some nice emails from my boss, and from my boss' boss, and my boss' boss' boss. So after that I kind of put it aside... Once it was done and I knew that the money went out and closed the project I was very relieved and then once I got the emails it was just further reinforcement that we had done a good job". “...it was very frustrating while it was happening, but then once it was done, it was done, you know? The issue was that there was a legal document that needed to be filed like in the middle of my vacation. I had no idea about it. So once the thing was final, it was done. And so it was very easy to move on after that. I wasn't dreading on dealing with this when I was back in the office".

Conversely, this comment demonstrates strain-based work-to-life conflict and an inability to detach from work after a stressful reaction to an interrole transition experience:

"I have had a long history of working in mental health. So through the years, I often go in to this kind of, I don't want to say numb, but I go in to this calm mode of thinking logically about what needs to get done, and then later... that is when I am like 'oh my god.' So at that movement, I was very much in planning mode, but later, when I was like going to sleep, I was just thinking a lot about... and I am sure you can realize this with psychologists... You tend to have these moments where it's like 'Wow the world is a really shitty place.' You start to think 'It sucks that this side of society and these experiences that people live through.' Ultimately I was thinking, 'I can't protect all of the students I work with' and it's the awareness of that, that can be so saddening sometimes".

Episodic outcomes are expected to be related to longterm outcomes (P9), which include general effects on work (negative, neutral/mixed, and positive) and nonwork life (extent of enrichment vs. work-to-nonwork interference and ambivalence about how work and personal life interact). The following comments are responses to the question of how an interrole transition experience affected the individual in the long-term. The first comment shows how a social worker's interrole transition experience and her negative affective reactions to the experience accumulated and thus had long-term negative effects on her work (i.e., job burnout):

"Definitely I think first of all, even though I like my job, some of its difficult, and it definitely set the tone after going into a hospital and kind of managing a negative situation. It definitely, I kind of had a little gray cloud over my head the rest of the day so I would say it kind of set a negative tone for the day and then also just you know I think also it's kind of a tiring job and I benefit from having Saturday and Sunday off and on this day, not that I worked a whole eight hour day, I felt like I didn't get that break cause its like really important to have so I would say not only did it impact my overall positive mood but it also just added to feeling tired about work in general".

This comment illustrates how an interrole transition made a young mother leave her job (i.e., negative effect on work):

"...That was very particular to just having a baby, first baby, not knowing boundaries, and working for someone who had no respect for those boundaries whatsoever. And you want to ask about emotions...that was the point at which I started looking for a new job here, because I just associated the city with a certain amount of pressure and no respect for work-life balance. But I just remember, sorry I'm getting very emotional, but I just remember being on the train and thinking, 'what am I doing?"' 
This comment demonstrates how an interrole transition experience turned into a learning experience as the situation helped a young man do his job better (i.e., positive effect on work):

"It was just a little bit of a learning experience like the issue that came up wasn't something that ya know I had anticipated or the people I was working with had anticipated. And after speaking to my boss who got involved ya know he wasn't pointing fingers but it was something that probably should have come up early. But it wasn't like a bad thing it was just one of those kind of a teaching point type things".

The following comment shows how an interrole transition positively impacted the young mother as it led to a job that enriched her personal life (i.e., positive effect on nonwork life):

“...it was a disaster in a way. But...It actually worked out very well. Long term, very positive impact...had things been a little uncomfortable but bearable I think I would have stayed in the situation. But when things got extreme it made me think that I can't even work in the city...And now I'm grateful, I'm home before 5 which many working mothers cannot say that. I have a good chunk of time in the evening to spend with family...the experience made me move in a direction that I just wouldn't have thought to...".

The next comment illustrates how an interrole transition experience made a psychologist feel both good and bad (i.e., ambivalent) about how work affects her personally:

"So then I start thinking about when I worked in-inpatient, and I thought about this child that I was working with who I found out was sexually abused by six different people in his family...I started thinking about him, and like 'what is he up to?' It rekindles a lot of tough emotions. I am still learning how to, even though I have worked in mental health a long time, I still haven't figured out a good formula about how to feel better. I don't think there is ever a way to. I think it is just more about the awareness and sadly, the acceptance to some degree that there is going to be horrible things that people befall, but to then work more on how I can help to promote healing".

This last comment shows how an interrole transition made a young woman feel that her work negatively impacts her personal life:

"...She is the only one who had my cell phone number that night...Again, I don't set good boundaries. Work-life balance for me, is completely skewed. I am only thirty-six. I don't date. I am newly single, for a lot of reasons...”.

\section{Discussion}

Work-related ICT use during nonwork time may boost productivity and work engagement [13, 14, 16, 29]; however, interruptions at home and ensuing interrole transitions can be disruptive and taxing due to a misalignment between purpose (i.e., work) and context (i.e., home; [3, 6, 7]). Given continued proliferation of ICTs that blur work-nonwork boundaries $[50,51]$ and potential consequences for worker well-being $[11-13,15,17,33,35]$, the present study was designed to develop a data-driven episodic model illuminat- ing the underlying mechanisms translating interruptions into interrole transitions and subsequently into adverse outcomes for individuals. Thus, this research contributes to the ICT literature with a testable model illuminating two parts of $\mathrm{Hu}$ et al.'s [3] ICT taxonomy-ICT-related interruptions and ICT use during nonwork time. The present study also complements Puranik et al.'s [19] process model of how, when, and why interruptions at work impact employees. Lastly, this study answers Ashforth et al.'s [2] call for more research specifying the mechanisms underlying how individuals manage their work and nonwork boundaries, enhancing scholars and practitioners' understanding of how and why interruptions at home beget interrole transitions which subsequently affect individuals in different ways.

A two-phased qualitative investigation using the event reconstruction method revealed rich and detailed accounts of work interrupting personal life via ICTs, with interruptions as the key stimulus event catalyzing an interrole transition response [20]. Content analysis helped identify the fundamental characteristics of interruptions at home, the defining features and underlying mechanisms of interrole transitions, and outcomes of these experiences. In particular, the findings highlighted the various interrelated stages of this process, highlighting its complexity beyond a simple stimulus-response event. Moreover, content analysis revealed how cognitive appraisals and affective reactions that occur several times throughout the experience influence work and well-being outcomes. An episodic process model depicting these mechanisms with testable propositions was developed, setting the stage for future ICT and WF research, which may also inform organizational intervention plans and strategies.

Findings suggest that context at the individual level (e.g., preferences for integrating work and nonwork roles) and organizational level (e.g., workplace support for work-life balance) influence individual perceptions and appraisals of interruptions as well as their reactions to them. This recognized importance of context is aligned with prior research showing that individual preferences and organizational norms regarding work-nonwork integration influence work-related ICT use during nonwork time [36].

Results suggest that certain interruption characteristics (e.g., unpredictable timing) distinguish unexpected interruptions at home from planned work-related ICT use during nonwork time (e.g., invited client calls). Further, various interruption characteristics (e.g., timing, content, and tone) play a role in how individuals immediately react to interruptions. These findings build on prior research showing that sender tone affects how individuals react to email messages [42] by identifying additional critical interruption characteristics that may affect interruption appraisals and reactions. Although characteristics of interruptions at work have been well delineated (e.g., [41]), the present study contributes to the ICT and WF bodies of literature with a model incorporating various characteristics of interruptions at home, which may also help in understanding reactions to interruptions. Findings indicate that immediate responses include appraisals of an interruption's predictability and legitimacy which then may trigger affective reactions, with this chain 
reaction depending on interruption timing, message, and tone. These results expand on prior research focused on how variability in interruption frequency is related to immediate affective reactions (e.g., [6]). The present study also identified variability in interruption predictability and legitimacy as critical to consider when trying to understand immediate affective reactions. Horvath et al.'s [43] research on interruptions at work underscores these findings, as they found that interruption importance was a key factor predicting affective reactions. Thus, interruption importance may be relevant regardless of the domain of occurrence.

The results also suggest that an unplanned interrole transition is unique from planned ICT use during nonwork time (e.g., routine after-hours email checking), as an unplanned interrole transition is a necessary response to cope with interruptions at home. This finding aligns with Matthews et al. [33] who found that interrole transitions serve as a short-term coping mechanism in response to role overload. In regards to factors that may predict responding to interruptions, prior studies have examined one's ability and willingness to flex a role boundary as well as role integration preferences as predictors of interrole transitions (e.g., $[34,36])$. Yet, because the present study focused on unexpected interruptions at home over which individuals may not have control, the results build on prior research by identifying interruption predictability and legitimacy as important factors that may affect decisions to transition between roles.

The findings also suggest important characteristics of interrole transitions that make each one unique, with variations in type (e.g., email vs. phone call), timing, and duration as determinants of appraisals and affective reactions to the transition experiences which then have further outcomes (e.g., work-to-family conflict). These findings support Butts et al. [42] who considered ICT use during nonwork time as within-person events with specific qualities that determine responses and outcomes. They found the time required to respond to a work-related email during nonwork time was associated with anger which was then related to work-tononwork conflict. Likewise, when responding to interruptions at home, underlying qualities of the interrole transition may impact its judged legitimacy, predictability, productivity, and difficulty. Research on interrole transition appraisals and reactions has been very limited. Ashforth et al. [2] argued that the difficulty of role transitions is important to consider when determining its impact on individuals, but the appraisal process has not been empirically examined before. As the content analysis uncovered the importance of appraisals, the present study adds to the boundary management literature.

The findings for the outcomes of interruptions and interrole transitions are aligned with prior research. Despite interruptions and interrole transitions having some positive effects on work (e.g., completion of unfinished work tasks) and nonwork life (e.g., feelings of enrichment), the content analysis also revealed that these experiences may immediately contribute to negative affect [37] and then a lack of work detachment [70], which may ultimately contribute to work-to-family conflict (e.g., $[11,12])$ and negative work attitudes (e.g., [71]). These results are supported by Chen and Karahanna's [18] review which found that after-hourswork can have positive effects on work via task closure, but that interruption overload and interrole transitions also have negative effects (e.g., work exhaustion).

5.1. Theoretical Implications. By integrating ideas from ICT and boundary research, the present study contributes to the WF and ICT bodies of literature with the development a testable data-driven model that comprehensively captures the lifespan of an interruption at home. First, the findings build on the foundational research conducted on boundary management and interrole transitions. Ashforth et al. [2] and Clark [27] introduced role transitioning as a process that could occur between work and nonwork roles via weak work-nonwork boundaries. Clark [45] acknowledged that individuals may not always have control over work permeations into nonwork domains, bringing attention to unplanned role transitions. Later, Kreiner et al. [8] made the critical distinction between boundary violations and generalized WFC. The present study's results demonstrated that ICTs can weaken boundaries, as work unexpectedly violated participants' nonwork boundaries via emails and phone calls, even while on vacation in remote places. The results also add to prior studies that have separated boundary violation experiences from reactions to the experiences (e.g., [6, 42]) by identifying the underlying mechanisms and stages of both the interruption event and the interrole transitions that occur in response to the interruption, thereby clarifying the boundary management process $[2,72]$.

With a focus on two critical parts of Hu et al.'s [3] ICT taxonomy-ICT-related interruptions and ICT use during nonwork time-the results help explain how a misalignment between ICT purpose (i.e., for work) and context (i.e., at home) can make interruptions feel like violations of personal boundaries and thus be problematic for individuals, despite any potential for work productivity. For example, various characteristics of an interruption (e.g., timing) may influence the extent to which it is appraised as legitimate and subsequently the extent of negative affective reaction. Likewise, various characteristics of an interrole transition (e.g., duration) may impact how it is appraised (e.g., extent of difficulty or productivity), and these appraisals may then influence nonwork life (e.g., extent of mental detachment from work), which then may impact various work and nonwork attitudes. Therefore, the results and corresponding process model helped clarify how and why ICT-related interruptions at home translate into interrole transition responses which then have various consequences for employees.

The developed process model also complements Puranik et al.'s [19] process model of interruptions at work, which illustrates how and why work interruptions impact performance and well-being outcomes via various mediators (e.g., affect, goal progress, and attention residue), paralleling the work and nonwork outcomes outlined in the present model. Puranik et al.'s model also clarifies when work interruptions have these effects with consideration of attributes of the context (e.g., organizational culture), interrupting task (e.g., duration), interrupted task (e.g., timing), and individual (e.g., 
conscientiousness and self-efficacy). The present process model also considers attributes of the context and individual specifically in relation to factors affecting work-nonwork boundaries (e.g., perceived organizational support for worklife balance, and boundary preferences), as well as underlying attributes of the interrupted task (e.g., timing) and interrupting tasks (e.g., duration). Yet, the process model developed in the present study diverges from Puranik et al.'s model by addressing appraisals and attributes of the critical interrole transition process (e.g., response time and duration).

Finally, the findings expand on Maertz et al.'s [48] model with evidence that the processing of WFC episodes may depend on the type of perceived WF incompatibility experienced. ICT-related interruptions at home are a particular type of WFC episode that is becoming more pervasive as employees increasingly utilize ICTs and work remotely [50]. A process model focused on interruptions at home and associated interrole transitions as a specific type of WFC episode is necessary to advancing boundary theory.

5.2. Practical Implications. Given the potential for shortterm and long-term negative outcomes suggested by the results, it is critical that employers help employees manage the increasing prevalence of ICT-related interruptions at home, especially for remote workers who may be more likely to experience these interruptions [50]. The findings provide insight into what factors translate interruptions into interrole transitions (e.g., interruption legitimacy) and which interrole transition characteristics translate into adverse work and nonwork outcomes (e.g., transition difficulty). Employers can use this knowledge when designing relevant organizational interventions. Indeed, Piszczek and Berg [73] called for organizations to take a more prominent role in helping employees manage their work-nonwork roles and boundaries. Interventions can focus on helping employees choose when to respond to interruptions and educating managers on when interruptions are warranted, thereby potentially limiting negative outcomes for employees. For example, given the importance of interruption predictability and legitimacy, the findings suggest that managers be more selective when deciding whether to unexpectedly email or call someone during after-hours. Also, for warranted interruptions, it may be beneficial to set organizational guidelines on timing to help make these incidents more predictable for employees.

5.3. Limitations. Despite the theoretical and practical contributions of the newly developed episodic process model, there are some limitations that can be addressed in future research. The phase one sample was limited to participants from one metropolitan area in the United States known to have high work stress levels to ensure participants would experience ICT-related interruptions during nonwork hours. To test the model's generalizability, future research should be conducted with participants from various parts of the country and different cultural contexts, as interruptions may be perceived differently depending on work stress levels and cultural values regarding work and family.

A second limitation was the convenience sampling technique with participants in the author's personal network for phase one. Although this approach helped ensure participants met the study criteria and thus would be able to provide detailed descriptions of interruptions, it could lead to biases during the interview process, such as a social desirability effect resulting in less candid responses. Although phase two data improved upon these limitations with participants recruited via social networking websites throughout the United States, the sample primarily included individuals with more than four years of college education, thereby potentially limiting the range of socioeconomic statuses represented. Additionally, data were based on a single source, yet the phenomenon studied occurred in the home environment and/or during nonwork hours when many participants were not alone. Gathering data from partners or children could provide additional perspective. Also, although a small sample was necessary for an in-depth investigation of events in employees' lives, the model was based on only 37 participants and thus requires validation. Finally, memorable interruptions may have helped with recall accuracy, but were also likely emotionally charged and thus may have had a more negative impact on individuals than less memorable events. Hence, future research testing the model propositions should be based on larger, more diverse, multisource samples using the experience sampling method so that a wide variety of interruption events are examined.

The proposed model is a detailed representation of the interruption-response process, yet future research can further develop the model in several ways. Although the interviews addressed family contextual variables (e.g., whether family activities were interrupted, etc.), work context emerged as more important in the content analysis. Yet, the model could be expanded to address how family (e.g., partners and children) influences reactions and responses to ICT-related interruptions at home, as well as how family members are impacted. Also, the model could be bidirectional if integrated with Puranik et al.'s [19] model of interruptions at work. Lastly, a more dynamic model might address the role of time to examine the accumulated impact of ICT-related interruptions at home, daily patterns of workto-family interference following interruptions, or how interruptions influence earlier parts of the process thereby altering future perceptions (e.g., work-to-family interference from one interruption may impact legitimacy perceptions of future interruptions).

\section{Conclusion}

The qualitative design and event reconstruction method utilized in the present study helped reveal the underlying interrelated mechanisms linking ICT-related interruptions at home with interrole transition responses, helping to develop two key constructs from $\mathrm{Hu}$ et al.'s [3] ICT taxonomy: ICTrelated interruptions and ICT use during nonwork time. The results were used to facilitate the development of a process model of interruptions at home that complements Puranik et al.'s [19] process model of interruptions at work. An ICT-related interruption at home is positioned as the key stimulating event that may catalyze an interrole transition response and subsequent work and nonwork outcomes. 
Hence, the present study helped illuminate how and why interruptions at home may translate into interrole transition responses and subsequently different outcomes for employees. Testable propositions were developed to help stimulate future research and thereby advance ICT research and boundary management theory. This research is particularly important and timely, as employees may be increasingly likely to work remotely at least on a part-time basis.

\section{Appendix}

\section{A. Phase 1 Interview Protocol}

Interviewer prompts and follow-up questions are listed below each interview question.

(1) Please tell me about a planned, expected, or anticipated work task/activity that you performed during your personal time while in a nonwork location such as home. Please be as detailed as possible about the experience

(i) What type of work task/activity is it?

(ii) Who do you typically communicate with when performing this planned work task, if anyone?

(iii) How often do you perform this planned work task/activity during your personal time?

(iv) What typically leads up to the work task/ activity? Which day of the week do you perform the task?

(v) What time do you perform the task? What are you typically doing at the time you switch to your work tasks? Who is usually with you at the time?

(vi) Why do you perform this planned work task/ activity outside of your workplace during your personal time?

(vii) How long does it typically take to participate in this planned work task/activity?

(viii) How did you feel about the work task/activity? How intrusive or disruptive is the work task/activity to your personal time? If it is disruptive, why?

(ix) How do the people you are with react (if with anyone at the time)?

(x) How difficult is it to perform the work task/ activity?

(2) What impact does this work experience have on you during your personal time?

(i) What impact did your behavior have on your nonwork task/activity? (ii) What impact did your behavior have on others who were with you at the time?

(iii) Did you think about it afterward? How did you feel afterward?

(3) Please tell to me how disruptive this planned work task/activity is to your personal time, on a scale of one to seven, with one being "not at all disruptive" and seven being "extremely disruptive"

(4) How difficult is it for you to perform this planned work task/activity on a scale of one to seven, with one being "not at all difficult" and seven being "very difficult”

(5) Now please tell me about a specific time within the past month or so when work unexpectedly intruded upon or interrupted your personal time while in a nonwork location, such as your home. Please be as detailed as possible when you describe the work intrusion or interruption. The intrusion can be through technology or stemming from yourself

(i) What led up to the intrusion? What day/time was it, did anything significant happen at work that day if it was a work day, what were you doing at the time of the intrusion, were you with anyone at the time, if so who were you with at the time, did anything significant happen during your nonwork hours that day?

(ii) What happened?

(iii) Who was the source of the intrusion?

(iv) If the intrusion came from someone besides you, what form of communication was used?

(v) What was the content of the intrusion?

(vi) How anticipated or expected was the intrusion? How intrusive was the work interruption? How urgent did you perceive the work matter to be?

(6) How did you feel about the work intrusion?

(i) What were you thinking and feeling at that moment you experienced the intrusion?

(ii) How disruptive to your personal time did you perceive the intrusion to be? Why?

(iii) How did the people you were with react (if with anyone at the time)?

(7) How did you respond to the intrusion? Responses can be behavioral or psychological, such as brainstorming or mentally planning for a meeting

(i) Did you think any further about the work issue?

(ii) Why did you respond that way? 
(iii) If you decided to ignore the intrusion, why did you ignore it? How difficult was it to ignore it? Did you feel pressure to ignore the intrusion? If so, what or who made you feel pressured?

(iv) Was your decision to ignore the intrusion supported by those with you at the time? How did they feel about the intrusion?

(8) (Ask only if participant decided to respond to the intrusion by role switching.) Why did you respond that way?

(i) Was your decision to switch roles supported by those with you at the time? How did they feel about it?

(ii) How difficult was it to respond?

(iii) How disruptive was it to your personal time?

(9) What impact did your decision to (ignore/respond) to the work intrusion have on you?

(i) What impact did your response have on your nonwork task/activity?

(ii) What impact did your response have on others who were with you at the time?

(iii) Did you think about the work intrusion afterward? If so, for how long? What did you think about? How did you feel afterward?

(10) Based on the experience you just described, please tell me how unexpected the work intrusion was for you on a scale of one to seven, with one being "not at all unexpected" and seven being "extremely unexpected"

(11) How intrusive was the work intrusion on a scale of one to seven, with one being "not at all intrusive" and seven being "extremely intrusive?"

(12) How urgent did the work intrusion seem to be, on a scale of one to seven, with one being "not at all urgent" and seven being "extremely urgent?"

(13) How disruptive was the work intrusion to your personal time, on a scale of one to seven, with one being "not at all disruptive" and seven being "extremely disruptive?"

(14) (Ask only if participant ignored the intrusion.) How difficult it was for you to ignore the intrusion on a scale of one to seven, with one being "not at all difficult" and seven being "very difficult?" (Ask these two questions only if the participant responded to the work intrusion.)

(15) How disruptive to your personal time was it to switch roles, on a scale of one to seven, with one being "not at all disruptive" and seven being "extremely disruptive>?"
(16) Now please tell me how difficult it was for you to switch from your nonwork task or activity to the work task on a scale of one to seven, with one being "not at all difficult" and seven being "very difficult?"

\section{B. Phase 2 Interview Protocol}

Interviewer prompts and follow-up questions are listed below each interview question.

(1) Tell me about the type of work that you typically do when you are away from your workplace, outside of your normal business hours?

(2) Okay, now tell me about a specific time when you unexpectedly had to work while away from your workplace, outside of your normal business hours. This would be unplanned work during your personal time while away from your workplace. What happened?

(i) Was this routine work or something out of the ordinary or unusual?

(ii) If routine or typical, how often do you do this type of work? (If routine, do not gather anymore details; continue to Q3. If unusual/atypical, prompt for details, then skip to Q4.)

(iii) What day of the week did this happen? What time did this happen?

(iv) How were you feeling that day? And right before it happened?

(v) What were you doing at the time? Were you with anyone at the time? If so, who?

(vi) If someone from work contacted you, who was it? How were you contacted?

(vii) What was the content of the message? What was the tone of the message?

(3) Now can you tell me about a time when you unexpectedly had to do any unusual work while away from your workplace, outside of normal business hours? This would be any out of the ordinary work you unexpectedly have to do during your personal time while away from your workplace. Please explain what happened

(i) What day of the week did this happen? What time did this happen? What were you doing at the time? Were you with anyone at the time? If so, who? How were you feeling that day? And right before it happened?

(ii) If someone from work contacted you, who was it? How were you contacted?

(iii) What was the content of the message? What was the tone of the message? 
(iv) What was your immediate reaction? Please be specific as possible. What were you thinking at the time? What were you feeling at the time? Why did you react this way?

(v) If someone was with you at the time, what did they think and feel about it?

(vi) What did you do about it? Please be specific as possible. Did you respond or ignore it? If you ignored it, why? Why did you respond this way?

(vii) How much time and effort did you spend on it?

(viii) How did you feel about your response?

(ix) If someone was with you at the time, what did they feel about your response?

(x) What impact, if any, did this experience have on you? Please be as specific as possible. How did it affect you? Did it affect your thoughts? How? Did it affect your mood? How? Did it affect what you were doing at the time? How?

(xi) Did it affect anyone you were with at the time? How? Did it affect anyone else?

(xii) Did it have any long-term impact on you? Did you think about it afterward? For how long? Did if affect you the next day? How?

(4) Looking back, what do you think about this experience? How do you feel about it? (If it was a negative experience, return to Q3 and ask the same set of questions for a positive experience. If the experience was positive, return to Q3 and ask the same set of questions for a negative experience. Once positive and negative UNUSUAL experiences are shared, end the interview with the final set of questions further below.)

\section{Data Availability}

The interview data used to support the findings of this study are available from the corresponding author upon reasonable request.

\section{Conflicts of Interest}

The author declares that they have no conflicts of interest.

\section{References}

[1] D. L. Blustein, R. Duffy, J. A. Ferreira, V. Cohen-Scali, R. G. Cinamon, and B. A. Allan, "Unemployment in the time of COVID-19: a research agenda," Journal of Vocational Behavior, vol. 119, p. 103436, 2020.

[2] B. E. Ashforth, G. E. Kreiner, and M. Fugate, "All in a day's work: boundaries and micro role transitions," Academy of Management Review, vol. 25, no. 3, pp. 472-491, 2000.
[3] X. Hu, Y. Park, A. Day, and L. K. Barber, "Time to disentangle the information and communication technology (ICT) constructs: developing a taxonomy around ICT use for occupational health research," Occupational Health Science, vol. 5, no. 1-2, pp. 217-245, 2021.

[4] Y. Park, Y. Liu, and L. Headrick, "Improving lives of teachers: staying connected to work, work-family boundary control, and strain," in Academy of management proceedings (Vol. 2018, no. 1, p. 13441), Academy of Management, Briarcliff Manor, NY 10510, 2018.

[5] M. M. Piszczek, "Boundary control and controlled boundaries: organizational expectations for technology use at the workfamily interface," Journal of Organizational Behavior, vol. 38, no. 4, pp. 592-611, 2017.

[6] E. M. Hunter, M. A. Clark, and D. S. Carlson, "Violating workfamily boundaries: reactions to interruptions at work and home," Journal of Management, vol. 45, no. 3, pp. 12841308, 2019.

[7] K. Kerman, C. Korunka, and S. Tement, "Work and home boundary violations during the COVID-19 pandemic: the role of segmentation preferences and unfinished tasks," Applied Psychology, 2021.

[8] G. E. Kreiner, E. C. Hollensbe, and M. L. Sheep, "Balancing borders and bridges: negotiating the work-home interface via boundary work tactics," Academy of Management Journal, vol. 52, no. 4, pp. 704-730, 2009.

[9] R. A. Matthews and J. L. Barnes-Farrell, "Development and initial evaluation of an enhanced measure of boundary flexibility for the work and family domains," Journal of Occupational Health Psychology, vol. 15, no. 3, pp. 330-346, 2010.

[10] S. Xu and Z. Wang, "The immediate and delayed impact of multitasking on well-being: an experience sampling study," Human Behavior and Emerging Technologies, vol. 3, no. 5, pp. 710-719, 2021.

[11] F. Gaudioso, O. Turel, and C. Galimberti, “The mediating roles of strain facets and coping strategies in translating technostressors into adverse job outcomes," Computers in Human Behavior, vol. 69, pp. 189-196, 2017.

[12] K. J. Harris, R. B. Harris, J. R. Carlson, and D. S. Carlson, "Resource loss from technology overload and its impact on work-family conflict: can leaders help?," Computers in Human Behavior, vol. 50, pp. 411-417, 2015.

[13] L. Lieke, C. L. ter Hoeven, and M. Toniolo-Barrios, "Staying in the loop: is constant connectivity to work good or bad for work performance?," Journal of Vocational Behavior, vol. 128, p. 103589, 2021.

[14] J. M. Ragsdale and C. S. Hoover, "Cell phones during nonwork time: a source of job demands and resources," Computers in Human Behavior, vol. 57, pp. 54-60, 2016.

[15] A. M. Santuzzi and L. K. Barber, "Workplace telepressure and worker well-being: the intervening role of psychological detachment," Occupational Health Science, vol. 2, no. 4, pp. 337-363, 2018.

[16] C. L. Ter Hoeven, W. van Zoonen, and K. L. Fonner, “The practical paradox of technology: the influence of communication technology use on employee burnout and engagement," Communication Monographs, vol. 83, no. 2, pp. 239-263, 2016.

[17] D. S. Carlson, M. J. Thompson, and K. M. Kacmar, "Double crossed: the spillover and crossover effects of work demands on work outcomes through the family," Journal of Applied Psychology, vol. 104, no. 2, pp. 2144-2228, 2019. 
[18] A. Chen and E. Karahanna, "Life interrupted: the effects of technology-mediated work interruptions on work and nonwork outcomes," MIS Quarterly, vol. 42, no. 4, pp. 10231042, 2018.

[19] H. Puranik, J. Koopman, and H. C. Vough, "Pardon the interruption: an integrative review and future research agenda for research on work interruptions," Journal of Management, vol. 46, no. 6, pp. 806-842, 2020.

[20] F. P. Morgeson, T. R. Mitchell, and D. Liu, "Event system theory: an event-oriented approach to the organizational sciences," Academy of Management Review, vol. 40, no. 4, pp. 515-537, 2015.

[21] R. G. Barker, "The stream of behavior as an empirical problem," in The Stream of Behavior, R. G. Barker, Ed., pp. 1-22, Appelton-Century-Crofts, 1963.

[22] J. W. Creswell and C. N. Poth, Qualitative inquiry and research design: choosing among five approaches, Sage Publications, 2017.

[23] A. Strauss and J. Corbin, Basics of Qualitative Research: Techniques and Procedures for Developing Grounded Theory, Sage Publications, 2nd edition, 1998.

[24] E. Zerubavel, The Fine Line, Free Press, New York, NY, USA, 1991.

[25] E. Zerubavel, Social Mindscapes: An Invitation to Cognitive Sociology, Harvard University Press, Cambridge, MA, USA, 1996.

[26] C. Nippert-Eng, "Calendars and keys: the classification of "home" and "work"," Sociological Forum, vol. 11, no. 3, pp. 563-582, 1996.

[27] S. C. Clark, "Work/family border theory: a new theory of work/family balance," Human Relations, vol. 53, no. 6, pp. 747-770, 2000.

[28] D. T. Hall and J. Richter, "Balancing work life and home life: what can organizations do to help?," Academy of Management Perspectives, vol. 2, no. 3, pp. 213-223, 1988.

[29] I. Diaz, D. S. Chiaburu, R. D. Zimmerman, and W. R. Boswell, "Communication technology: pros and cons of constant connection to work," Journal of Vocational Behavior, vol. 80, no. 2, pp. 500-508, 2012, https://doi-org.www.library .manhattan.edu/10.1016/j.jvb.2011.08.007.

[30] A. R. Grotto and K. S. Lyness, "What a week! A moderatedmediation crossover model for daily boundary violations at home and partner evening affect," Stress and Health, 2021.

[31] B. T. McDaniel, K. O'Connor, and M. Drouin, "Work-related technoference at home and feelings of work spillover, overload, life satisfaction and job satisfaction," International Journal of Workplace Health Management, vol. 14, no. 5, pp. 526-541, 2021.

[32] U. Kinnunen, T. Feldt, J. de Bloom, M. Sianoja, K. Korpela, and S. Geurts, "Linking boundary crossing from work to nonwork to work-related rumination across time: a variable- and person-oriented approach," Journal of Occupational Health Psychology, vol. 22, no. 4, pp. 467-480, 2017, https://doi-org .www.library.manhattan.edu/10.1037/ocp0000037.

[33] R. A. Matthews, D. E. Winkel, and J. H. Wayne, "A longitudinal examination of role overload and work-family conflict: the mediating role of interdomain transitions," Journal of Organizational Behavior, vol. 35, no. 1, pp. 72-91, 2014, https://doiorg.www.library.manhattan.edu/10.1002/job.1855.

[34] D. E. Winkel and R. W. Clayton, "Transitioning between work and family roles as a function of boundary flexibility and role salience," Journal of Vocational Behavior, vol. 76, no. 2, pp. 336-343, 2010, https://doi-org.www.library.manhattan .edu/10.1016/j.jvb.2009.10.011.

[35] D. Derks, H. van Mierlo, and E. B. Schmitz, "A diary study on work-related smartphone use, psychological detachment and exhaustion: examining the role of the perceived segmentation norm," Journal of Occupational Health Psychology, vol. 19, no. 1, pp. 74-84, 2014.

[36] N. Gadeyne, M. Verbruggen, J. Delanoeije, and R. De Cooman, "All wired, all tired? Work-related ICT-use outside work hours and work-to-home conflict: the role of integration preference, integration norms and work demands," Journal of Vocational Behavior, vol. 107, pp. 86-99, 2018.

[37] S. Lutz, F. M. Schneider, and P. Vorderer, "On the downside of mobile communication: an experimental study about the influence of setting-inconsistent pressure on employees' emotional well-being," Computers in Human Behavior, vol. 105, article 106216, 2020.

[38] M. Mazmanian, W. J. Orlikowski, and J. Yates, "The autonomy paradox: the implications of mobile email devices for knowledge professionals," Organization Science, vol. 24, no. 5, pp. 1337-1357, 2013.

[39] M. Tarafdar, J. Darcy, O. Turel, and A. Gupta, "The dark side of information technology," MIT Sloan Management Review, vol. 56, no. 2, pp. 61-70, 2015.

[40] M. Wan, M. A. Shaffer, T. Lau, and E. Cheung, "The knife cuts on both sides: examining the relationship between crossdomain communication and work-family interface," Journal of Occupational and Organizational Psychology, vol. 92, no. 4, pp. 978-1019, 2019.

[41] E. Russell, T. Jackson, and A. Banks, "Classifying computermediated communication (CMC) interruptions at work using control as a key delineator," Behaviour \& Information Technology, vol. 40, no. 2, pp. 191-205, 2021.

[42] M. M. Butts, W. J. Becker, and W. R. Boswell, "Hot buttons and time sinks: the effects of electronic communication during nonwork time on emotions and work-nonwork conflict," Academy of Management Journal, vol. 58, no. 3, pp. 763-788, 2015.

[43] M. Horvath, J. S. Gueulette, and K. A. Gray, "Employee reactions to interruptions from family during work," Occupational Health Science, vol. 5, pp. 141-162, 2021.

[44] K. M. Shockley and T. D. Allen, "Deciding between work and family: an episodic approach," Personnel Psychology, vol. 68, no. 2, pp. 283-318, 2015.

[45] S. C. Clark, "Communicating across the work/home border," Community, Work \& Family, vol. 5, no. 1, pp. 23-48, 2002.

[46] R. Hamilton, K. D. Vohs, A.-L. Sellier, and T. Meyvis, "Being of two minds: switching mindsets exhausts self-regulatory resources," Organizational Behavior and Human Decision Processes, vol. 115, no. 1, pp. 13-24, 2011.

[47] S. Leroy, A. M. Schmidt, and N. Madjar, "Interruptions and task transitions: understanding their characteristics, processes, and consequences," Academy of Management Annals, vol. 14, no. 2, pp. 661-694, 2020.

[48] C. P. Maertz, S. L. Boyar, and P. W. Maloney, "A theory of work-family conflict episode processing," Journal of Vocational Behavior, vol. 115, p. 103331, 2019.

[49] S. Sonnentag and I. Braun, "Not always a sweet home: family and job responsibilities constrain recovery processes," in New Frontiers in Work and Family Research, J. G. Grzywacz and E. Demerouti, Eds., pp. 71-92, Psychology Press, 2013. 
[50] J. Delanoeije, M. Verbruggen, and L. Germeys, "Boundary role transitions: a day-to-day approach to explain the effects of home-based telework on work-to-home conflict and hometo-work conflict," Human Relations, vol. 72, no. 12, pp. 1843-1868, 2019.

[51] J. Fisher, J.-C. Languilaire, R. Lawthom et al., "Community, work, and family in times of COVID-19," Community Work \& Family, vol. 23, no. 3, pp. 247-252, 2020.

[52] D. Vargo, L. Zhu, B. Benwell, and Z. Yan, "Digital technology use duringCOVID-19 pandemic: a rapid review," Human Behavior and Emerging Technologies, vol. 3, no. 1, pp. 13-24, 2021.

[53] J. W. Creswell, Qualitative Inquiry and Research Design: Choosing among Five Approaches, Sage Publications, 3rd edition, 2013.

[54] A. Day, S. Paquet, N. Scott, and L. Hambley, "Perceived information and communication technology (ICT) demands on employee outcomes: the moderating effect of organizational ICT support," Journal of Occupational Health Psychology, vol. 17, no. 4, pp. 473-491, 2012.

[55] J. Dettmers, T. Vahle-Hinz, E. Bamberg, N. Friedrich, and M. Keller, "Extended work availability and its relation with start-of-day mood and cortisol," Journal of Occupational Health Psychology, vol. 21, no. 1, pp. 105-118, 2016.

[56] A. McCann, "2021's most \& least stressed cities in America," Wallter Hub, 2021, July 2021, https://wallethub.com/edu/ most-least-stressed-cities/22759.

[57] G. Hertel and C. Stamov-Roßnagel, "Reconstruction methods: using episodic memory traces to capture experiences at work efficiently," in Current Issues in Work and Organizational Psychology. A Day in the Life of a Happy Worker, A. B. Bakker and K. Daniels, Eds., pp. 100-113, Psychology Press, 2013.

[58] D. Kahneman, A. B. Krueger, D. A. Schkade, N. Schwarz, and A. A. Stone, "A survey method for characterizing daily life experience: the day reconstruction method," Science, vol. 306, no. 5702, pp. 1776-1780, 2004.

[59] E. Diener and L. Tay, "Review of the day reconstruction method (DRM)," Social Indicators Research, vol. 116, no. 1, pp. 255-267, 2014.

[60] L. D. Butterfield, W. A. Borgen, N. E. Amundson, and A.-S. T. Maglio, "Fifty years of the critical incident technique: 19542004 and beyond," Qualitative Research, vol. 5, no. 4, pp. 475-497, 2005.

[61] T. R. Hinkin, "A brief tutorial on the development of measures for use in survey questionnaires," Organizational Research Methods, vol. 1, no. 1, pp. 104-121, 1998.

[62] S. Sonnentag, "Working in a network context-what are we talking about? Comment on Symon," Journal of Occupational and Organizational Psychology, vol. 73, no. 4, pp. 415-418, 2000.

[63] R. E. Boyatzis, Transforming Qualitative Information: Thematic Analysis and Code Development, Sage Publications, 1998.

[64] W. L. Miller and B. F. Crabtree, "Primary care research: a multimethod typology and qualitative road map," in Doing Qualitative Research, B. F. Crabtree and W. L. Miller, Eds., pp. 3-28, Sage Publications, 1992.

[65] E. A. Weitzman and M. B. Miles, Computer Programs for Qualitative Data Analysis: A Software Sourcebook, Sage Publications, 1995.
[66] J. Lofland and L. H. Lofland, "Developing analysis," in Analyzing Social Settings, J. Lofland and L. H. Lofland, Eds., pp. 181203, Wadsworth, 1995.

[67] C. L. Williams, P. A. Giuffre, and K. Dellinger, "Sexuality in the workplace: organizational control, sexual harassment, and the pursuit of pleasure," Annual Review of Sociology, vol. 25, no. 1, pp. 73-93, 1999.

[68] S. A. Lawrence, J. Gardner, and V. J. Callan, “The support appraisal for work stressors inventory: construction and initial validation," Journal of Vocational Behavior, vol. 70, no. 1, pp. 172-204, 2007.

[69] K. Locke, Grounded theory in management research, Sage Publications, 2001.

[70] A. Firoozabadi, S. Uitdewilligen, and F. R. H. Zijlstra, "Should you switch off or stay engaged? The consequences of thinking about work on the trajectory of psychological well-being over time," Journal of Occupational Health Psychology, vol. 23, no. 2, pp. 278-288, 2018.

[71] S. Sonnentag, C. Binnewies, and E. J. Mojza, "Staying well and engaged when demands are high: the role of psychological detachment," Journal of Applied Psychology, vol. 95, no. 5, pp. 965-976, 2010.

[72] T. D. Allen, E. Cho, and L. L. Meier, "Work-family boundary dynamics," Annual Review of Organizational Psychology and Organizational Behavior, vol. 1, no. 1, pp. 99-121, 2014.

[73] M. M. Piszczek and P. Berg, "Expanding the boundaries of boundary theory: regulative institutions and work-family role management," Human Relations, vol. 67, no. 12, pp. 14911512, 2014. 